\title{
Long term stability of a terrestrial cave community
}

\author{
Claudio Di Russo *, Gianmaria Carchini *, Mauro Rampini **, \\ Marco Lucarelli * and Valerio Sbordoni *
}

\begin{abstract}
SUMMARY
We report data on the spatial structure and seasonal variation of the community of Valmarino cave, a medium sized sandstone cave, located a few kilometres from the coast line, in Central Italy. Due to both its habitat features and its relatively recent geological history, Valmarino cave is only inhabited by terrestrial, troglophilic elements, i.e, facultative cave dwellers.

By means of monthly censuses and density plot estimates we have investigated species abundance, diversity and their spatial organization, by considering separately samples from different cave sectors. Homogeneous sampling design allowed to compare series of samplings performed in 1974 and 1994.

On the whole 21 arthropods and one snail species constitute the cave community. Ordination plots resulting from correspondence analyses of monthly samples outline a distinct spatial and temporal structure. Two main sub-communities can be identified: a inner subcommunity, mainly represented by eu-troglophilic species, showing a remarkable stability throughout the year and an outer sub-community, mainly represented by sub-troglophilic species, showing strong seasonal variation. Both spatial and temporal vectors show similar importance in shaping the community structure.

An interesting result of this study is the long term stability of both spatial and seasonal components of the community structure which remained almost identical after 20 years, as shown by the comparison of ordination plots obtained from 1974 and 1994 sampling series. Therefore this study provides empirical evidence of a frequently hypothesised, albeit never demonstrated feature of the cave ecosystem.
\end{abstract}

\section{INTRODUCTION}

Caves are generally considered as simplified habitat for the absence of primary production and consequent reduction of the other trophic levels (Poulson \& White, 1969). The living organisms they harbour mainly depend on organic matters carried into caves by water, gravity and animals (Barr, 1967).

Caves are also regarded as habitats of great stability owing to their relatively constant micro-climate. Ecological theory predicts that stability

\footnotetext{
* Dipartimento di Biologia, Università degli Studi di Roma "Tor Vergata". Via della Ricerca Scientifica, 00133 Roma-Italy.

** Dipartimento di Biologia Animale e dell'Uomo, Università degli Studi di Roma "La Sapienza”. Viale dell'Università 32, 00185 Roma-Italy.
} 
of the habitat permits community stability (May, 1973). Furthermore stability as other features of communities need to be tested over long time period and must be calibrated on the basis of relative biogeographical and historical scenario of the studied system (Southwood, 1996). In fact, stability of the cave habitat is thought to represent a major factor affecting evolutionary responses in cave dwelling organisms (Vandel, 1964; Sbordoni, 1980; Culver, 1982). These and other features have often awarded caves as «natural laboratories» for the study of evolutionary and ecological processes. However, despite of these favourable conditions, only few and scattered researches were aimed to investigate variation of cave communities in space and time (Turquin et al., 1975; Howarth, 1981; Martin \& Oromi, 1986; Poulson, 1992).

Two recent studies showed the occurrence of significant variation in troglobite and cricket-guano communities of Australia and North America, respectively (Humphreys, 1991; Poulson et al., 1995), accounting for a strong dependence of these communities on unpredictable climate changes. These studies raise the question on the generality of the idea of stability of cave communities.

In order to contribute to this important debate, we report a series of data on a long-term investigation of a troglophilic community in the Grotta di Valmarino, a small cave near the Tyrrhenian coast line, in Central Italy. Researches started in 1974 and preliminary results were showed in several scientific meetings (Carchini et al., 1982; 1983; 1992). To test the occurrence of stability in space and time of this cave community, a second series of comparable surveys was carried out in 1994-95.

\section{MATERIAL AND METHODS}

Valmarino cave (register number $251 \mathrm{La}$ ) is a medium sized sandstone cave located about $150 \mathrm{Km}$ south of Rome, near to the coast line. We have chosen this cave for two important reasons: abundance of fauna and easily detectable cave walls for monitoring.

Detailed data on topography and geology of the cave are reported in Carchini et al. (1982). On the basis of stratigraphic and marine transgression data (Bigazzi et al., 1973) the cave was submerged until 230.000-200.000 years ago and therefore it was not available to colonisation by terrestrial organisms before that time.

Monthly censuses of parietal community (i.e.: the assemblage of organisms currently found on the walls) were carried out using density plot method (Seber, 1973). For this purpose the cave was divided into 6 sectors adapted to the cave topography. One additional sector located outside the 
cave entrance was also considered (Fig. 1). The whole area of the sampling surface, as estimated from the cave topographic survey, was 341 square metres. Cave climate was periodically checked. For each sector temperature and relative humidity were recorded using a thermo-hygrometer (Hanna Instruments $8564 ;{ }^{\circ} \mathrm{C} \pm 0.4^{\circ} \mathrm{C} ; \mathrm{RH} \pm 2 \%$ ). The main cave trophic resource is bat guano that occurs regularly only in the inner sector $\mathrm{G}$ on a surface of at least 10 square metres. In order to check variation of this trophic supply, bat colonies and guano surface were monitored during samplings in 1994. Other available resources were dung of other mammals like Vulpes vulpes, Hystrix crestata and Rattus norvegicus.

Analysis of community structure was carried out using multivariate approaches. Species density matrices for each sector and periodical censuses were processed by Factorial Corresponding Analysis (FCA). Abundance comparisons were tested by $\mathrm{t}$-test for dependent samples and Kolgomorov-Smirnov test. Relationships among species as prey/predator and seasonal associations were detected by simple regression analysis. Diversity of periodical samples was estimated by means of the Gini-Simpson index (Gini, 1912).

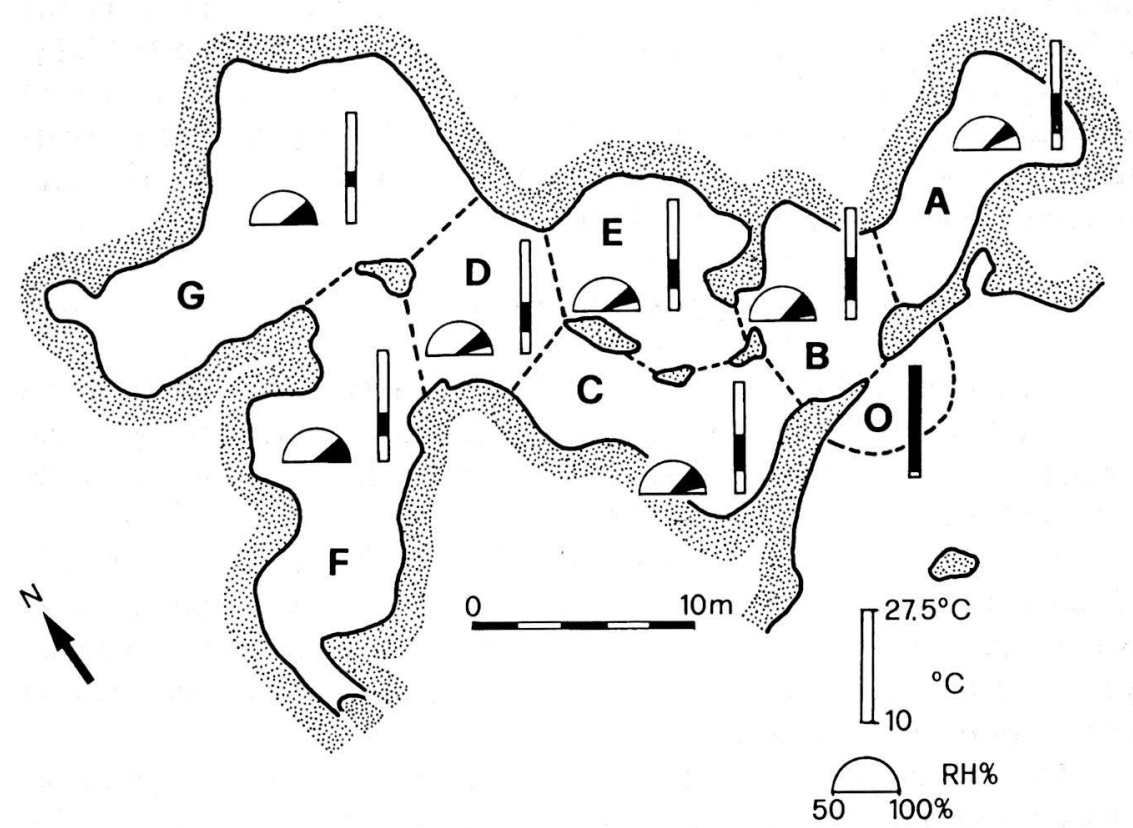

Fig. 1 - Map of Valmarino cave with the different sampling sectors and range of temperature and humidity recorded. 


\section{RESULTS}

\section{Cave climate}

Temperature and relative humidity were recorded for the two survey periods. As found in most of temperate caves the inner sectors ( $G$ and $F$ ) appear to be more stable than the other ones, showing an average temperature of $16.5^{\circ} \mathrm{C}$ and an annual variation limited to $1^{\circ} \mathrm{C}$. On the contrary, the sector closest to the entrance (B) showed a thermal variation of at least $5^{\circ} \mathrm{C}$, ranging between $14^{\circ} \mathrm{C}$ and $19^{\circ} \mathrm{C}$. As expected, inner and outer sectors reduce their thermal gap in autumn and spring. Finally, no significant difference was observed on the annual trend in temperature between the two sampling periods, 1974 and 1994. Relative humidity in 5 cave sectors was always maintained above $90 \%$. Only the sector B showed lower values (60\%).

\section{Community structure}

On the whole 22 troglophilic species, including Gastropods and Arthropods, appear to constitute the framework of the parietal community of Valmarino cave. We have not considered the species occasionally recorded in the cave. In Table 1 the list of species sampled is reported. We used the terms eutroglophile and subtroglophile, following a terminology currently used by European biospeleologists (Ruffo, 1959), where the first ones are considered more strictly linked to cave for reproduction, not necessarily showing troglomorphic features (i.e. blindness, depigmentation and elongation of appendages). On the contrary the subtroglophiles may occur periodically in cave without any particular morphological adaptation to cave life. Each species has also been characterised by its trophic role (Root, 1967). We have not found any strictly troglobite species and the ratio Eutroglophile/Total species was 0.27 . Concerning the trophic structure we found an high percentage of Predators $(53 \%)$ among species feeding inside the cave. The most abundant species were, in decreasing order, Culex pipiens, Limonia nubeculosa, Porcellionides pruinosus and Dolichopoda geniculata.

Fig. 2, represents the ordination plot from a FC analysis performed on the relative abundance of any species in each period and sector. Species show a distinct structure and different levels of clustering, largely corresponding to their dependence on season and sector, indicating their degree of troglophily. It is easy to argue that the first axis mainly represent seasonal variation, while the second axis represents spatial location, i.e.: sector. Eutroglophilic species as Oxychilus draparnaudi, Nesticus eremita, Dolichopoda geniculata, the endemic Tegenaria marinae and Callipus foe- 
tidissimus sorrentinus are closely grouped, toughly corresponding to the inner sectors $G$ and $F$. Location of this cluster near the centre of the first axis accounts for a modest, almost irrelevant, seasonal variation. On the contrary subtroglophilic species are scattered across sectors progressively close to the entrance. Among these, moths (A. spectrum and H. obsitalis) and mosquitoes ( $C$. pipiens), which tend to hibernate into the cave, show on the first axis an opposite location to Limonia nubeculosa, which behaves as an aestivating species. Only few species were recorded on the walls of the external sector $(\mathrm{O})$, namely the common spiders Tegenaria parietina and Pholcus phalangioides.

Table 1 - List of species sampled in Valmarino cave

\begin{tabular}{|c|c|c|c|}
\hline Taxa & Symbols & Category & Trophic role \\
\hline $\begin{array}{l}\text { Gastropoda } \\
\text { Oxychilus draparnaudi }\end{array}$ & OXY & Eutroglophile & Predator \\
\hline $\begin{array}{l}\text { Chilopoda } \\
\text { Scutigera coleoptrata }\end{array}$ & SCU & Subtroglophile & Predator \\
\hline $\begin{array}{l}\text { Diplopoda } \\
\text { Callipus } f . \text { sorrentinus }\end{array}$ & CAL & Eutroglophile & Detritivore \\
\hline $\begin{array}{l}\text { Aranae } \\
\text { Pholcus phalangioides }\end{array}$ & $\mathrm{PHO}$ & Subtroglophile & Predator \\
\hline Tegenaria parietina & PAR & Subtroglophile & Predator \\
\hline Tegenaria marinae & MAR & Eutroglophile & Predator \\
\hline Meta merianae & MER & Subtroglophile & Predator \\
\hline Nesticus eremita & NES & Eutroglophile & Predator \\
\hline $\begin{array}{l}\text { Isopoda } \\
\text { Porcellio dilatatus }\end{array}$ & EUP & Eutroglophile & Detritivore \\
\hline Armadillidium vulgare & ARM & Subtroglophile & Detritivore \\
\hline Porcellionides pruinosus & MET & Subtroglophile & Detritivore \\
\hline $\begin{array}{l}\text { Orthoptera } \\
\text { Gryllomorpha dalmatina }\end{array}$ & GRY & Subtroglophile & Scavenger \\
\hline Dolichopoda geniculata & DOL & Eutoglophile & Scavenger \\
\hline $\begin{array}{l}\text { Lepidoptera } \\
\text { Apopestes spectrum }\end{array}$ & APO & Subtroglophile & - \\
\hline Monopis sp. & MON & Subtroglophile & $\overline{-}$ \\
\hline Hypena obsitalis. & HYP & Subtroglophile & $\longrightarrow$ \\
\hline Microlepidoptera & MIC & Subtroglophile & $\longrightarrow$ \\
\hline $\begin{array}{l}\text { Diptera } \\
\text { Culex pipiens }\end{array}$ & CUL & Subtroglophile & \\
\hline Limonia nubeculosa & LIM & Subtroglophile & 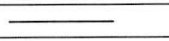 \\
\hline Brachycera & BRA & Subtroglophile & $\overline{ }$ \\
\hline Nematocera & NEM & Subtroglophile & ב \\
\hline Psychodidae & PSY & Subtroglophile & $\bar{Z}$ \\
\hline
\end{tabular}

Relationships between species were tested by simple regression analysis on the whole sample (1974-1994). Statistically significant correlations were found between abundances of species pairs, mostly due to the occurrence of similar seasonal behaviour. In two cases, however, such correlation might be 
interpreted as the effect of a prey/predator relationships as in the pair Pholcus-Porcellionides $(\mathrm{r}=0.67$ for 1974 and $\mathrm{r}=0.71$ for $1994, \mathrm{p}<0.01)$ and in the pair Culex-Scutigera $(r=0.86$ in 1974, $p<0.001$, and $r=0.51$ in 1994, $p<0.05$; see Fig. 3). Interesting enough is the seasonal vicariance between $C$. pipiens and the other most common dipteran species Limonia nubeculosa, indicating the occurrence of a marked temporal displacement of cave roosting of the two species (Fig. 3). In fact, the mosquito C. pipiens inhabits the cave for winter dormancy of pregnant females, while L. nubeculosa enter the cave only in late spring for aestivation.

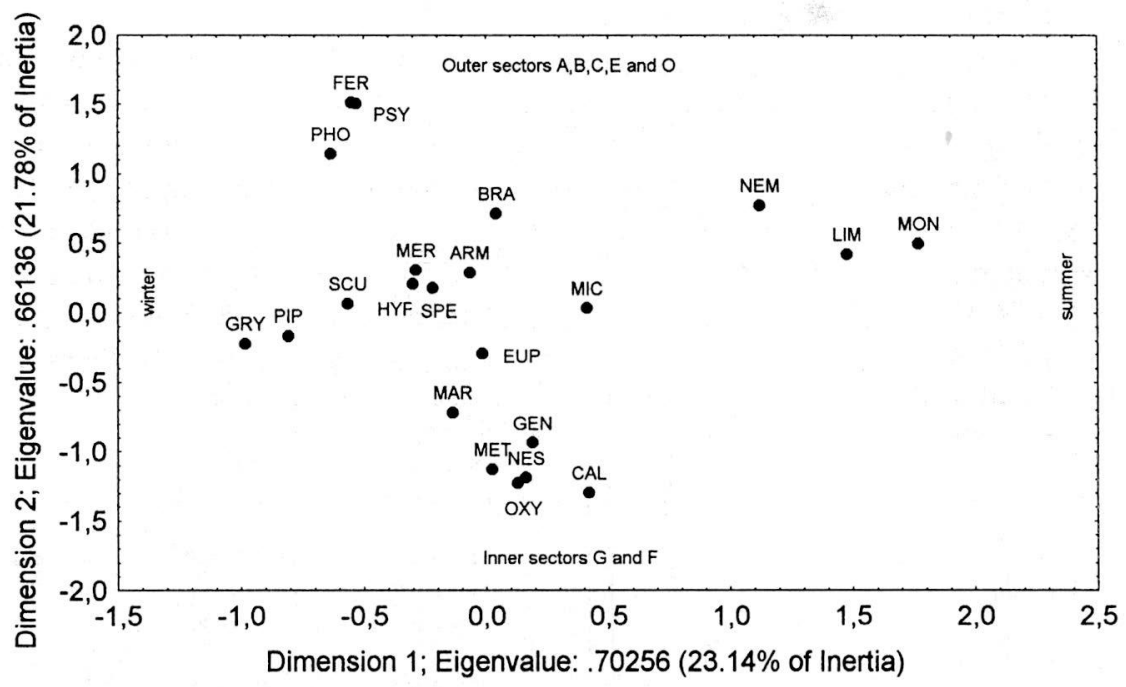

Fig. 2 - Correspondence Analysis performed on the relative abundance of any species in each period and sector (data from 1994 survey).

\section{Community structure variation}

Variation of the community structure in time and space is synthetically represented in the ordination plots reported in Fig. 4. These two plots, obtained from Correspondence Analyses of monthly censuses from different sectors, show a remarkable similarity between the two surveys of 1974 and 1994. In both surveys, samples are roughly arranged on a triangle, where the superior vertex corresponds to the inner sectors ( $G$ and $F)$ and the basis corresponds to the outer sectors (mainly A, B and C). In fact, the first axis mainly traces seasonal variation of community samples, while the second axis traces their spatial arrangement. In both surveys samples from inner 
sectors are closely grouped, showing a very small degree of seasonal variation. On the opposite samples from the outer sectors are largely spread on the first axis, showing substantial high seasonal variation in both surveys. As expected, samples from the intermediate sector E, occupy intermediate locations in respect of both axes, showing a lesser extent of seasonal variation than outer samples.

Variations of the Gini-Simpson diversity index are reported and compared in Fig. 5. Similar trends in seasonal variation are evident in both surveys, where most of the monthly values average 0.8 , but two major negative peaks occur in summer and late fall, corresponding to the massive arrival of L. nubeculosa and $C$. pipiens, respectively.

Finally, species abundance was also compared (Fig. 6). On the whole a general decrease for most taxa was observed, even if no local extinction apparently occurred. Such decline significantly affected eutroglophilic species and predators, as indicated by the t-test analysis for dependent samples (see asterisks on the histograms of Fig. 6). Decrease of bat guano was also estimated to occur by at least $50 \%$. It was apparently due to a consistent reduction of the bat colony, mainly represented by Rhinolophus euryale and Miniopterus schreibersi, which dropped roughly by a factor 10 , from an average of 300-400 individuals in 1974 to 35-40 in 1994.
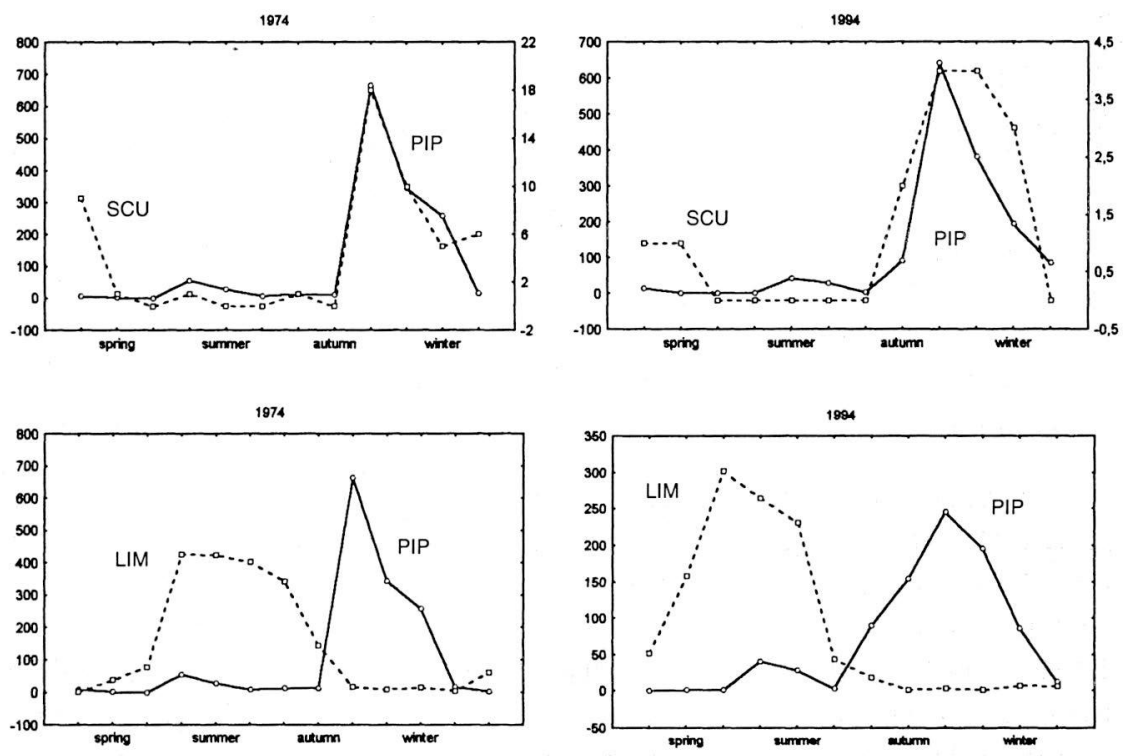

Fig. 3 - Variation in monthly abundance of Culex pipiens (PIP), Limonia nubeculosa (LIM) and Scutigera coleoptrata (SCU): a comparison between 1974 and 1994. 

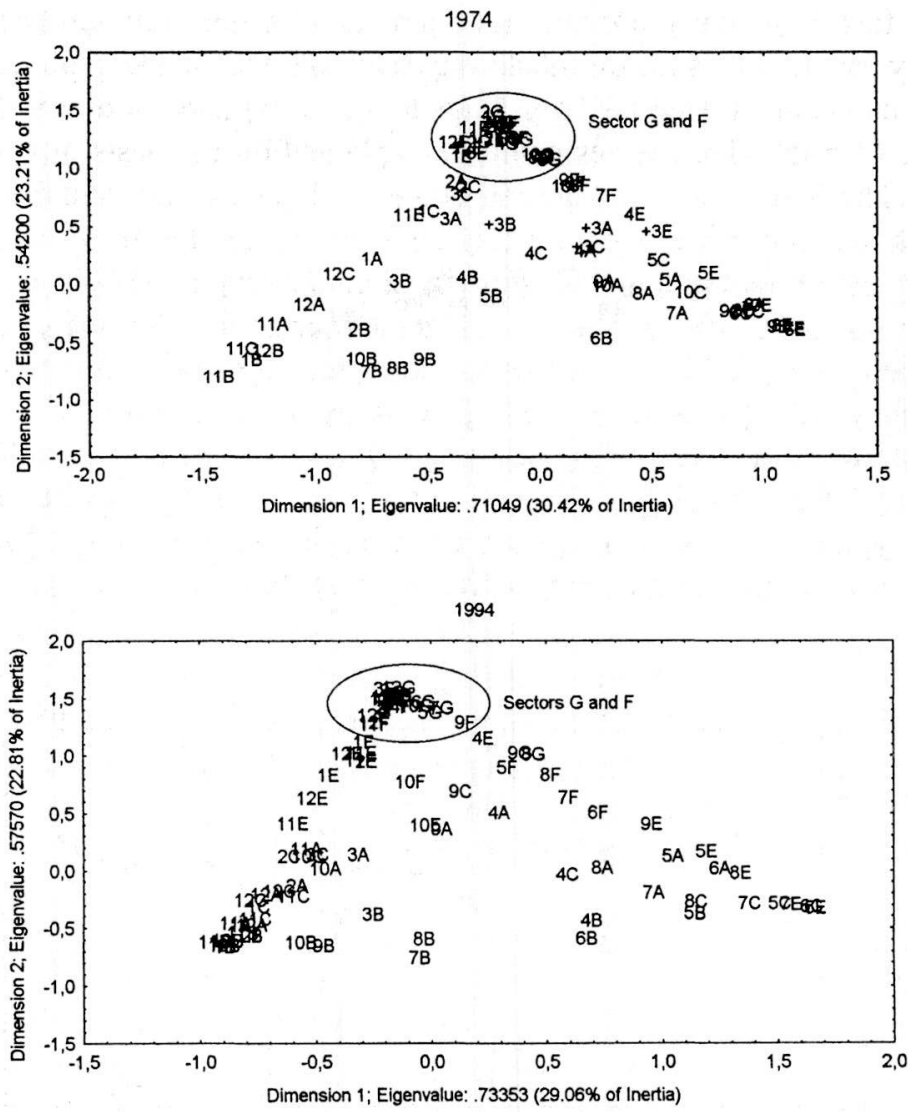

Fig. 4 - Correspondence Analyses of monthly samplings from 6 sectors in the Valmarino cave (see text for explainations).

However, frequency distributions of species throughout the whole cave, did not show statistically significant variation between the two surveys, as supported by means of a Kolgomorov-Smirnov test ( $p>0.1$ ), indicating that the relative composition of community remained similar and stable in a time span of 20 years.

\section{DISCUSSION}

Periodical samples investigated by means of density plot method allowed us to describe the structure of the parietal community at Valmarino cave and its variation in space and time. On the whole the species composi- 
tion of this community appears quite similar to other communities dominated by troglophilic species, inhabiting caves and man made hypogeans at a similar elevation in Central Italy (Capolongo, 1969; Sbordoni, 1971). The absence of troglobitic species could be explained on the basis of two main factors. The first is related to the sandstone origin of the cave and the lack of crevices and fissures preventing migration of troglobites from other cave systems and/or the underground superficial compartment (M.S.S. as defined by Juberthie et al., 1980). The second factor concerns evolutionary time and palaeogeographic evidence. In fact, stratigraphic data testify that Valmarino cave was submerged until 230.000-200.000 years ago (Bigazzi et al., 1973). However, even more recent marine trasgressions occurred in the late Pleistocene could have left little time and chance for troglobitic evolution. Accordingly, the cave community shows a rather low ratio eutroglophiles/total species (0.27), indicating its low degree of specialisation.
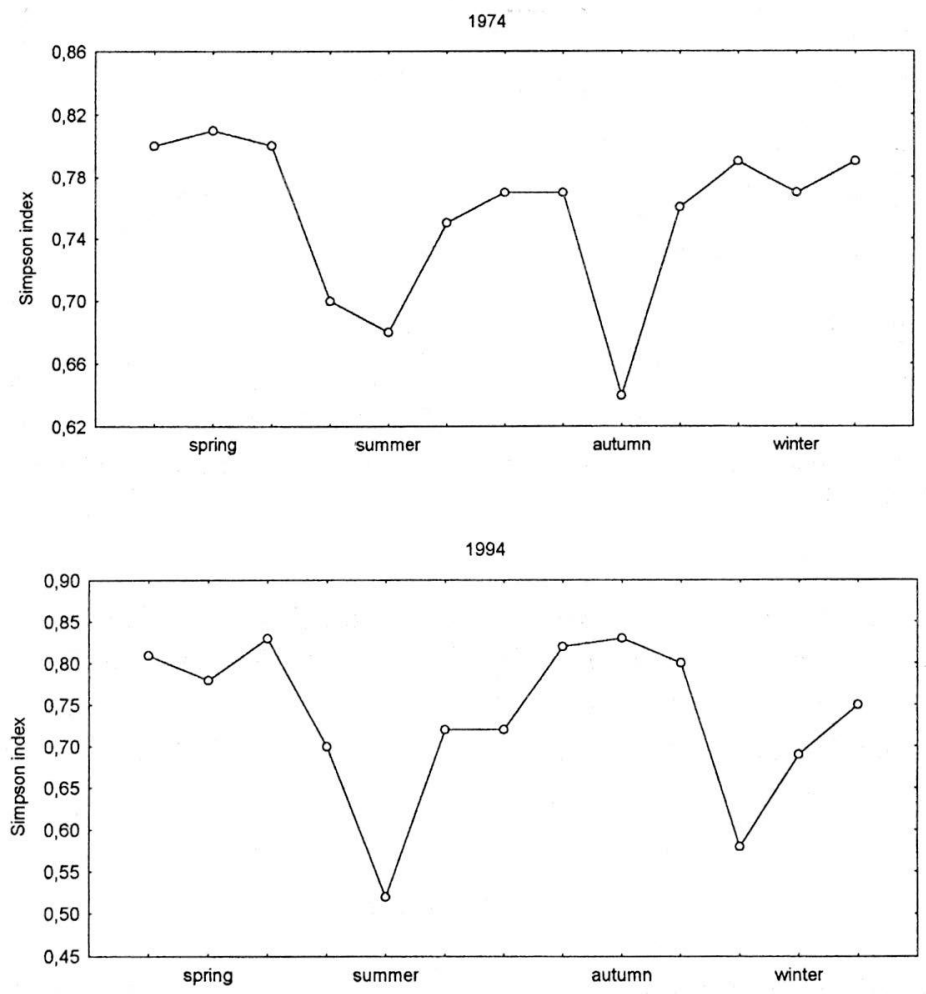

Fig. 5 - Monthly variation of the Gini-Simpson diversity index calculated for the cave community at Valmarino cave. 


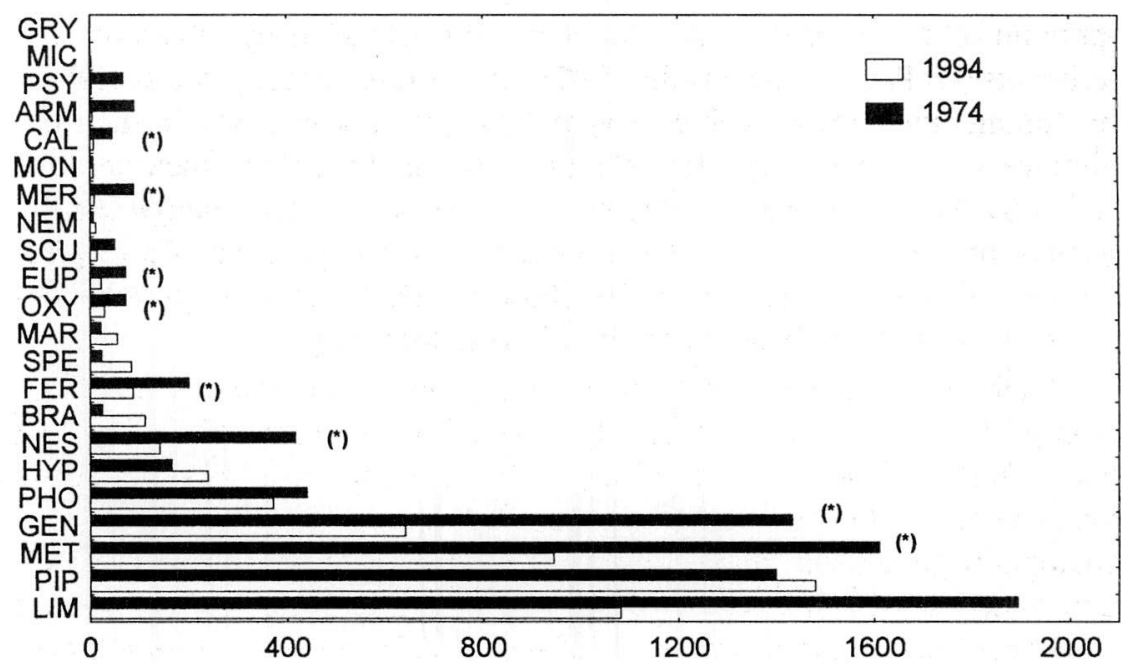

Fig. 6 - Total species abundance in Valmarino cave from two different years (1974 - 1994): asterisks indicate decreasing species.

The high percentage of predators found in the cave suggests that the community structure is basically controlled by predation. The role of predation in shaping the seasonal pattern of Valmarino cave community is also revealed by the occurrence of statistically significant correlations, ascertained in both sampling periods, between pairs of interacting taxa, such as Scutigera coleoptrata vs. Culex pipiens, and Pholcus phalangioides vs. Porcellionides pruinosus. Similar patterns were found in a cave of North West Cape Peninsula, W. Australia (Humphreys, 1991) and in the Mammoth cave, in Kentucky (Kane, 1974). In both cases the terrestrial communities appeared to hold many predator species. Evidence of narrow preypredator relationships was also found between the carabid beetle Neaphenops tellkampfi and the cricket eggs of Hadenoecus subterraneus (Kane, et al., 1975).

Several species exhibit a strong spatial structure and show stable associations in certain sectors, depending upon their degree of tolerance and the stability of microclimate. As expected, the most specialised cave organisms like Dolichopoda geniculata, Oxychilus draparnaudi, Callipus $f$. sorrentinus, Nesticus eremita, and others are toughly associated to the inner sectors $\mathrm{G}$ and $\mathrm{F}$. For some of these species reproduction and/or ovideposition only occur in these sectors whose climatic conditions appear to meet optimal requirements for some species. In the case of the cave cricket $D$. geniculata, the average temperature of the sector $\mathrm{G}\left(16^{\circ} \mathrm{C}\right)$ is very close to the thermal 
optimum of the embryonic development, as established by laboratory experiments (Di Russo \& Juberthie, 1995). On the other hand, other species in the community show a distinct temporal pattern of seasonality in their occurrence in the cave. Species relationships can be either sinchronic, as shown by the co-occurrence in winter of Culex pipiens and Scutigera coleoptrata, or allochronic, as in the two most common Dipterans: Culex pipiens and Limonia nubeculosa, which show seasonal vicariance in cave occupancy, due to their different timing of adult dormancy.

Such occurrence of strong spatial and temporal structures in the community of Valmarino cave is clearly reflected in the ordinations resulting from correspondence analyses which outline the existence of two opposite components within the cave community, i.e.: a component of subtroglophilic organisms characterised by strong seasonal behaviour mostly represented in the outer sectors, and a component of eutroglophilic species almost confined to the inner sectors of the cave. Interestingly enough, both the spatial and the time vectors show similar importance in determining the structure of this community.

Given these two major determinants of the community structure, the most important result obtained in this study is the high level of stability, over 20 years, showed by this cave community. The comparison of ordination plots of species samples, in space and time, shows surprisingly similar patterns in both periods of sampling (1974 and 1994).

The same conclusion can be drawn by comparing the seasonal behaviour of the Gini-Simpson diversity index, also accounting for a long term stability of the Valmarino cave community in both species composition and relative numbers of individuals in the various sectors of the cave.

Long term stability of cave communities is a feature claimed since early studies in biospeleology (Racovitza, 1907; Jeannel, 1926; Vandel, 1964), and this view inspired the refugium theory of cave evolution as well as concepts and ideas largely shared among early biospeleologists who considered troglobites as relics or even living fossils (Jeannel, 1943). On the other hand, as recently found by other authors (Humphreys, 1991; Poulson et al., 1995), environmental unpredictable stress could strongly affect stability of cave communities. In these examples, variation in resource input by cave crickets and water, respectively, determined significant qualitative and quantitative changes in the cave community.

Interestingly enough, an important reduction in energy supply also occurred in Valmarino cave, where the main resource, represented by bat guano deposits, met a substantial decrease. However, apparently, this change did not affect the qualitative composition of the community structure. Actually most 
of the eutroglophilic and predator species showed a sensible decrease in number, however no instance of local extinction was detected over twenty years. This findings suggest that the troglophilic community of Valmarino cave is subjected to a certain degree of «homeostasis» that allows to modulate its quantitative composition without altering its fundamental structure.

The question arises on how general is the pattern revealed in this study. Are caves really stable and predictable habitats in the long term? To what extent this is a feature of the cave environment? Unfortunately long term studies of community structures are still scanty. Lawton \& Gaston (1989) recorded the abundance of phytophagous insects on two patches of bracken over seven and fifteen years and found that their relative abundance changed hardly at all. Furthermore experimental studies of disturbance on some stream invertebrate community showed that quality and quantity of species declined with increasing disturbance intensity (Lake et al., 1989; Death, 1996). It could be expected that any disturbance applied on these environmental fragments result in community changes followed by more or less quick recovering, due to recolonization and migration between patch :s. Caves are more isolated habitats and are subjected to comparatively stable climatic regimes. In particular, limestone caves are thought to be almost free from medium frequency disturbance (Margalef, 1993) and our micro-climate data from various sectors of the Valmarino cave did not show any significant change over 20 years. Therefore results from this study seem to support May's view (May, 1973) that community stability depends chiefly on the stability of all factors that contribute to their physical environment.

\section{ACKNOWLEDGEMENTS}

Several people contributed to the development of this study. Particularly we are grateful to R. Galbiati for his friendly collaboration in the sampling operations in the cave. We also thank P. Matarazzo, D. Cesaroni, E. Fresi and M. Scardi for the help and the valuable suggestions on the data treatment. This study was supported by grants from Italian MURST and Italian CNR to G. Carchini and V. Sbordoni.

\section{REFERENCES}

BARR T.C. 1967. Observation on the ecology of caves. Am. Nat. 101: 475-492

BIGAZZI G., F.P. BONADONNA, S. IACCARINO. 1973. Geochronological hypothesis on plio-pleistocene bourdary in Latium region (Italy). Boll. Soc. Geol. It. 92: 391-422.

CAPOLONGO D. 1969. Studio ecologico delle cantine del napoletano. Boll. Soc. Entomol. Ital. 99-101: 193-205.

CARCHINI G., G. GIGLIO, M. RAMPINI, V. SBORDONI. 1982. Studi ecologici nella Grotta di Valmarino. I: Morfologia, clima, datazione e popolamento faunistico. Lav. Soc. It. Biogeogr. (n.s.) 7: 869-892

CARCHINI G., M. RAMPINI, V. SBORDONI. 1983. La comunità troglofila della Grotta di Valmarino: patterns spaziali e temporali. Atti XIII Congr. Naz.It. Ent., Sestriere-Torino, 1983: 295-298. 
CARCHINI G., V. SBORDONI, M. RAMPINI, P. MATARAZZO, M. SCARDI, E. FRESI. 1992. An analysis of troglophilic community in a mediterranean lowland cave. International Symposium of Biospeleology. Tenerife 7-12 septembre 1992.

CULVER D.C. 1982. Cave life. Evolution and Ecology. Harvard University Press, Cambridge Mass.

DEATH R.G. 1996. The effect of patch disturbance on stream invertebrate communty structure: the influence of disturbance history. Oecologia 108: 567- 576.

DI RUSSO C. \& C. JUBERTHIE. 1995 Effetto della temperatura sullo sviluppo embrionale di Dolichopoda. Fragm. Entomol. 27(1): 51-59.

GINI C. 1912. Variabilità e mutabilità. Studi econ. Giur. Fac. Giurisp. Univ. Cagliari.

HOWARTH F.G. 1981.Community structure and niche differentiation in Hawaiian lava tube In: MUELLER-DOMBOIS D., BRIDGES K.W. \& CARSON H.L. (Eds.), Island Ecosystems: Biological Organization in Selected Hawaiian Communities: 318-336. US/IBP Synthesis Series N 15. Stroudsberg, Pennsylvania: Hutchinson Ross.

HUMPHREYS W.F. 1991. Experimental re-establishment of pulse-driven populations in a terrestrial troglobite community. J. Anim. Ecol. 60: 609-623.

KANE T.C.1974. Studies of simple cave communities: predation strategies of two cooccurring carabid beetles. Ph.D. dissertation, University of Notre Dame, Cincinnati, $\mathrm{OH}$.

KANE T.C., R. M. NORTON \& T.L. POULSON. 1975. The ecology of a predaceous troglobitic beetle, Neaphaenops tellkampfii (Coleoptera: Carabidae, Trechinae). I. Seasonality of food input and early life history stages. Int. J. Speleol. 7: 45-54.

JEANNEL R. 1926. Faune cavernicole de France avec un étude des conditions d'existence dans le domain souterrain. Le Chevalier, Paris.

JEANNEL R. 1943. Les fossiles vivants des cavernes. Gallimard, Paris.

JUBERTHIE C., B. DELAY \& M. BOUILLON M. 1980. Extension du milieu souterrain en zone non calcaire: description d'un nouveau milieu et de son peuplement par les coléopteres troglobies. Mem. Biospeol. 7: 19-52.

LAKE P.S., T.J. DOEG., R. MARCHANT. 1989. Effect of multiple disturbance on macroinvertebrate communities in the Acheron River, Victoria. Aust. J. Ecol. 14: 507-514.

LAWTON J.H. \& K.J. GASTON. 1989. Temporal patterns in the herbivorous insects of bracken: a test of community predictability. J. Anim. Ecol. 59: 1021-1034.

MARTIN J.L. \& P. OROMI. 1986. An ecological study of Cueva de los Roques (Tenerife, Canary Island) J. Nat. Hist. 20: 375-388.

MAY R.M. 1973. Stability and complexity in model ecosystems. Princeton. New Jersey: Princeton University Press.

MARGALEF R. 1993. Troglobionts and modes of evolution. Mem. Biospeol. 20: 13-17.

POULSON T.L. 1992. The Mammoth Cave ecosystem. In: CAMACHO A. (Ed.). The natural history of Biospeleology. Monographs Natl. Mus. Nat. Sci. Madrid, Spain.

POULSON T.L. \& W.B. WHITE. 1969. The cave environment. Science165: 971-981.

POULSON T.L., K.H. LAVOIE \& K. HELF. 1995. Long-term effects of weather on the cricket (Hadenoecus subterraneus, Orthoptera, Rhaphidophoridae) guano Community in Mammoth Cave National Park. Am. Midl. Nat. 134: 226-236.

RACOVITZA E.G. 1907. Essai sur les problèmes biospéologique. Arch. Zool. exp. et gén. 6: 371-488.

ROOT R.B. 1967. The niche exploitation pattern of the blue-gray gnatcatcher. Ecol. Monogr. 37: 317-350.

RUFFO S.1959. La fauna delle caverne. In: La Fauna, T.C.I. Milano.

SBORDONI V. 1971. Osservazioni biogeografiche sulla fauna cavernicola dell'Appennino centrale. Lavori Soc. It. Biogeogr. (n.s.) (1973) 2: 594-614

SBORDONI V. 1980. Strategie adattative negli animali cavernicoli: uno studio di genetica di popolazione. Acc. Naz. Lincei 51: 61-100.

SEBER G. A. 1973. The estimation of animal abundance. Griffin, London

SOUTHWOOD T.R.E. 1996. Natural communities: structure and dynamics. Phil. Trans. R. Soc. Lond. B. 351: 1113-1129 
TURQUIN M.J., Y. BOUVET, PH. RENAULT \& E. PATTEE. 1975. Essai de corrélation entre la géomorphologie d'une cavité et la répartition spatiale de son peuplement actuel. Actes du $5^{\circ}$ Congrès suisse de Spéléologie, Interlaken, septembre 1974.

VANDEL A. 1964. Biospéologie: la biologie des animaux cavernicoles. Gauthier-Villars, Paris. 